\title{
Energy Research in Airports: A Review
}

\author{
Sergio Ortega Alba ${ }^{1}$ and Mario Manana ${ }^{2, *}$ \\ 1 Airport Seve Ballesteros-Santander, Aeropuertos Españoles y Navegación Aérea (AENA), Carretera del \\ Aeropuerto s/n, 39600 Maliaño, Cantabria, Spain; sortega@aena.es \\ 2 Department of Electrical and Energy Engineering, University of Cantabria, Avda. los Castros s/n, \\ 39005 Santander, Cantabria, Spain \\ * Correspondence: mananam@unican.es; Tel.: +34-942-201-378
}

Academic Editor: Antonella Battaglini

Received: 15 March 2016; Accepted: 3 May 2016; Published: 7 May 2016

\begin{abstract}
The main function of an airport is to provide access to air transport both for passengers and cargo. The number of air operations over the past 20 years has increased rapidly, and this has led to a rise in the energy needs of airports to satisfy this demand. As a consequence, the cost of energy supply for airport managers has escalated. At the same time, global energy consumption has soared due to the needs of emerging countries like China and India, with the consequent environmental impact. This complex scenario of environmental and economic factors has made airport managers become aware of the need to reduce energy consumption as well as a more efficient use of it. The aim of this article is to analyze the main behaviors and energy trends at airports in more recent research, starting with the description of the main energy sources and consumers, the application of energy conservation and energy efficiency measures, the establishment of energy indicators and benchmarking between airports, as well as energy modeling and simulation.
\end{abstract}

Keywords: airports; energy building; energy efficiency; energy consumption; energy conservation; energy benchmarking; energy modeling; energy simulation; renewable sources; Combined heat and power (CHP) plants

\section{Introduction}

During the last two decades, the consumption of primary energy and $\mathrm{CO}_{2}$ emissions has grown $50 \%$ worldwide [1]. Today, despite the uncertainty about the economic growth outlook in the short and medium term, forecasts show that global energy demand will register a sharp rise and will increase by a third in the period 2015-2040 [2]. This rapid increase in energy consumption is likely to have a significant environmental impact in the near future, and may even cause supply problems in some areas.

Energy consumers are normally divided into three main sectors: industry, transport and others, including in the last one the sub-sectors of agriculture and building (services and residential) [3]. This services sub-sector covers all public and commercial buildings including many types of buildings such as schools, hotels, hospitals and airports, with a variety of power applications (heating, ventilation and air conditioning (HVAC), lighting, electromechanical facilities, etc.). The overall contribution of this building sector, both residential and services, to energy consumption has increased rapidly from values of $20 \%$ to $40 \%$ in some developed countries [3], as shown in Table 1 . For this reason, energy efficiency in this sector is now a major objective of energy policy at the regional, national and international level. 
Table 1. Final energy consumers by sector in 2011. Source: [2].

\begin{tabular}{cc}
\hline Sector & Percentage in the World (\%) \\
\hline Transportation & 28 \\
Industry & 31 \\
Residential & 22 \\
Commercial & 19 \\
\hline
\end{tabular}

Within the services sector, airports, due to their particular features, may resemble small cities [4]. They serve as nodes for local, national and global transport and facilitate the establishment of businesses and transactions. In 2014, the 400 airport members of Airports Council International Europe (ACI Europe) have facilitated the transport of 1800 million people and 18.4 million tons of cargo, using 1.8 million air operations [5]. Regarding economic impact, European airports directly employ over 12.3 million people, representing $4.1 \%$ of European gross domestic product (GDP) [5]. For their operation, airports need to consume large amounts of natural resources, and the most important of these resources is electricity. A key factor in order to reduce energy consumption at airports is to understand the energy use and consumption behavior, due to the multiple parameters and singularities that are involved. Therefore, airports are excellent candidates for energy research.

This work summarizes the current state-of-the-art of energy use behavior and trends in airports. The review is further divided into seven sections. The next section briefly explains various concepts of airports. The review continues by describing the main energy sources and consumers, and the application of energy conservation and energy efficiency measures at airports. Thereafter, the establishment of energy indicators and benchmarking between airports, as well as energy modeling and simulation are proposed. Finally, conclusions of this review are outlined in the last section.

\section{Brief Airport Concepts}

An airport is the defined area on land or water (including any buildings, installations, and equipment) intended to be used either wholly or in part for the arrival, departure and surface movement of aircraft [6]. Nowadays, airports may also satisfy other commercial, industrial, business and entertainment service needs.

Airport design has been widely discussed in several technical publications $[7,8]$, and is related to the technical field of airport engineering. Likewise, due to the need to regulate and standardize the rules for the circulation of air traffic and airport design, the International Civil Aviation Organization (ICAO) was created in 1947. Their standards and recommendations in the field of aviation and airport requirements are adopted by world aviation authorities. Its main document for airport design is called Annex XIV [6].

From an operational point of view, it is traditional to divide an airport into two main areas of activity: the landside and airside [7] (see Figure 1). On the landside, the passenger is the main customer. This means that all activities carried out in this area are aimed to satisfy their needs. The most important activities are related to the movement, processing, organization and control of the flow of passengers, baggage and cargo at terminal buildings, the means to facilitate this flow and the different means of land transport to access the terminal. Within the landside, there are a number of common facilities to all airports, such as the terminal building, cargo terminal and vehicle parking.

On the airside, the aircraft, and everything that relates to it, is the main customer. Aircraft operations are among the main processes (landing and taking off of aircraft and guidance to the apron), along with the organization and control of all facilities involved. Within the airside, there are some buildings and facilities that are common to all airports for air traffic operations, such as the control tower, airfield lighting and radio navigation systems, firefighting buildings, hangers and weather facilities, etc. 


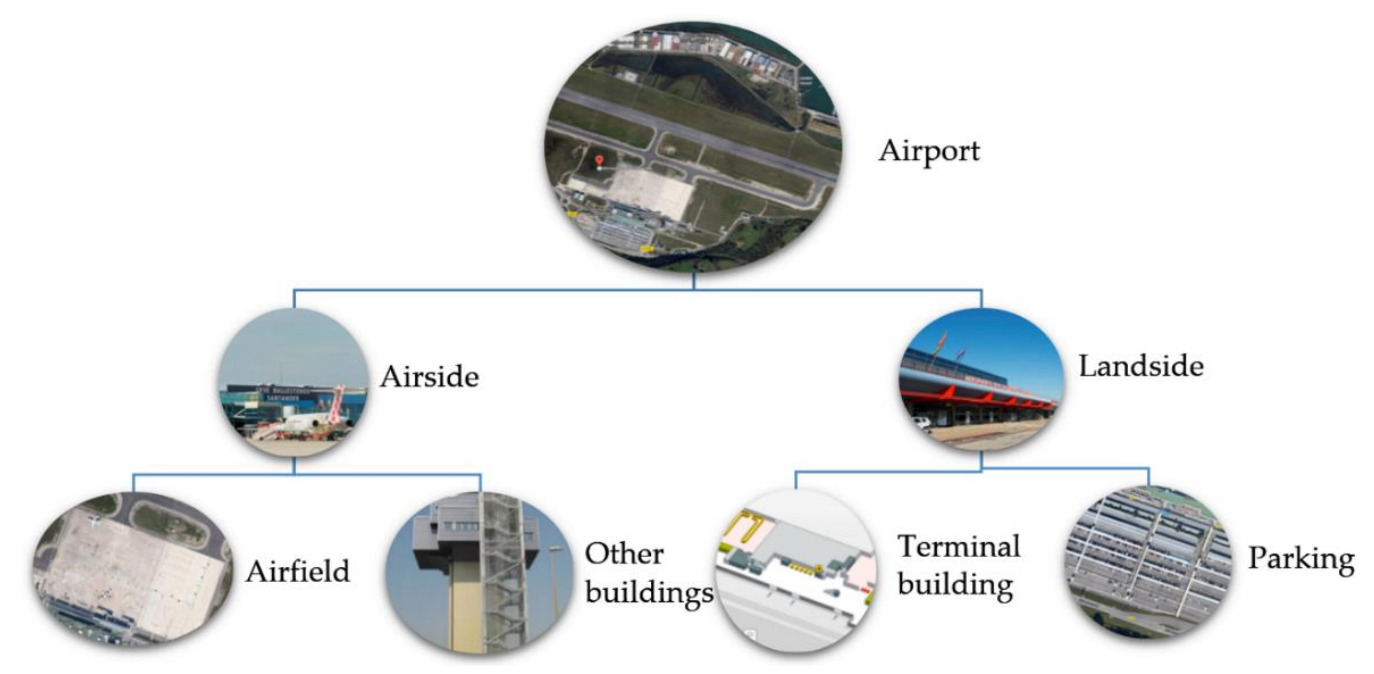

Figure 1. Scheme of main airport areas (Source: Airport Seve Ballesteros-Santander).

\section{Energy Sources}

In order to perform the multiple activities that are carried out in airports, both landside and airside, a certain amount of energy is necessary. The most important energy sources in airports are [9]:

1. Electricity: used for the operation of the various systems and facilities that are necessary in airports.

2. Fuel (natural gas, petrol, diesel, propane, etc.): used for heating boilers, catering or cogeneration power plants, emergency generators or vehicles.

Among these energy sources, electricity is the dominant one because it is necessary for the supply of the main airport energy consumers and to ensure the safety of air traffic operations, as shown in Table 2 for Spanish airports.

Table 2. Energy consumption in Spanish airports. Source: [9].

\begin{tabular}{cccc}
\hline \multirow{2}{*}{ Energy Source } & $\begin{array}{c}\text { Energy Consumption } \\
\mathbf{2 0 1 2}(\mathrm{GJ})\end{array}$ & $\begin{array}{c}\text { Energy Consumption } \\
\text { 2013 (GJ) }\end{array}$ & $\begin{array}{c}\text { Energy Consumption } \\
\mathbf{2 0 1 4}(\mathrm{GJ})\end{array}$ \\
\hline Electricity & $3,534,831$ & $3,338,549$ & $3,236,086$ \\
Fuel & 261,652 & 269,571 & 241,565 \\
\hline
\end{tabular}

GJ, Giga Joules.

This electricity usually comes from the commercial grid and is supplied by a power company. However, during the last several years it is possible to find in the scientific literature other kinds of energy sources such as cogeneration plants or renewable energy technologies, which can be utilized in airports.

\subsection{Cogeneration Plants}

Combined heat and power (CHP) technologies produce electricity or mechanical power, and recover waste heat for process use, achieving efficiencies up to 85\% [10]. In recent years, due to the large combined needs of electricity and heat in airports, CHP plants are being built. They need a connection between the internal and public grid to allow bidirectional power exchange, which also ensures system safety. At the same time, the heating energy produced can be used for air conditioning of the terminal buildings [11]. As an inconvenience, a CHP plant requires much more space than a conventional one, and it should be far enough from the runway and the control tower to avoid any electromagnetic interferences. 
In more recent research, Somcharoenwattanaa et al. [12] presented an analysis of a new $52.5 \mathrm{MWe}$ CHP plant at the Bangkok Suvarnabhumi airport, which provided an overall improvement in efficiency from $48 \%$ to $61 \%$, reducing by $24 \%$ the consumption of primary energy and achieving a $27 \%$ improvement in $\mathrm{CO}_{2}$ emissions. Falvo et al. [13] presented a $25.3 \mathrm{MWe} \mathrm{CHP}$ plant at the Rome Airport, used as a way to feed a district heating airport grid. Other examples are the $90 \mathrm{MWe}$ CHP plant at the John F. Kennedy (JFK) airport (New York, NY, USA) [14], the 18 MWe Frankfurt Rheiin/Main airport [15], and the 50 MWe CHP plant at Heathrow (London, UK) cited by Cardona [11].

In most cases, CHP plants are powered by natural gas as a primary energy source. However, other options such as the use of solar energy or biomass are available. Santoli et al. [16] propose a sustainable relationship between the territory and the infrastructure in terms of energy supply chain through the use of biomass, vegetable oil or biogas as a source of primary energy in the CHP plant at the Bari airport in Italy.

In southern climate zones and in airports with larger and regular demand profiles, trigeneration processes $(\mathrm{CHCP})$ can be technically and economically viable, generating cooling while producing electric power and heat [11]. The best examples are the 50 MWe CHCP plant at Malpensa (Milan, Italy) and the $40 \mathrm{MWe}$ CHCP plant at Kuala Lumpur (Malaysia). Cardona et al. [17] performed the planning and long-term simulation of a trigeneration plant for Malpensa airport, with favorable results for the implementation of the proposed repowering actions.

\subsection{Energy Renewable Sources}

Renewable technologies are considered as clean sources of energy and the optimal use of these resources minimizes environmental impact, produces minimum secondary wastes and is sustainable based on current and future economic and social needs [18]. Airports are located in optimal locations for the installation of renewable energy sources, allowing at least partial supply of their energy needs, and ensuring compliance with the highest international standards of safety [19,20]. Most of the practical experiences and scientific texts define a series of renewable energy technologies that could be used in airport facilities.

\subsubsection{Solar Energy}

Solar energy is obtained directly from the Sun and the incident radiation can be harnessed through photovoltaic cells to produce electricity directly or through thermal systems to produce heat, usable for in situ electricity generation or hot water systems [21]. Brief summaries for solar energy setups at Brainerd Lakes Airport in Minnesota and Toronto-Pearson Airport are provided in [19].

Airports are usually large, isolated and shading-free, presenting the perfect platform for the use of solar energy [22]. The smartest way to use this type of renewable energy is found in the field of architectural integration because conventional external building materials can be replaced [23]. The experiences in this field are positive regarding the use of photovoltaic modules as an additional envelope element. The possibilities for the installation locations are varied: roofs, walls, carports, curtain walls, etc.

As for the possible reflections of sunlight from solar panels that may affect the vison of cabin crews or control towers, Barret et al. [24] conclude that their effects are less dangerous than other surfaces existing at airports or surrounding areas (large groups of cars, lakes, etc.). Other studies show that deeply textured glass covers can solve this important issue [25].

Studies to determine the exact location of the solar panels must identify the location of the radio navigation systems to exclude unsuitable places that could block, reflect or disturb the electromagnetic signals [26]. It is also important to study the maximum height that solar panels can reach [20]. The location must also comply with the regulations regarding safety distances and recommendations related to areas of aircraft operations [27]. 
The effect of solar panels on biodiversity is studied by DeVault [28] due to the potential risk of attracting birds. The author proposes a bird hazard index and concludes that this kind of safety risk is not high, and therefore it is feasible to install solar panels at airports.

The energy demand patterns at airports in sunny and warm regions correlates well with solar generation profiles during the morning [22]. Nevertheless, the main problem with this type of energy in airports, as shown in the results of simulations in Brazilian airports by Braun et al. [29] is the mismatch between the production of photovoltaic energy and electricity consumption in the evening hours. Thus, the photovoltaic system is not able to cover the peak load of the network at night. To support these peaks is necessary to consider some form of energy storage technology.

The potential of this type of renewable energy is huge, and could lead to the emergence of economies of scale that could lower installation costs. Furthermore, this use at airports could generate a worldwide demand for large amounts of photovoltaic modules, which could represent a solar energy market worth billions of euros [30].

\subsubsection{Wind Energy}

Wind energy is potentially a very useful source of renewable energy for airports, due to the fact that airports typically contain large unoccupied areas. Examples of this type of energy source can be found at Gran Canaria Airport [9] or at Burlington International Airport [19]. However, airports have severe limitations on the placement of obstacles that may restrict the practical location of wind turbines near the airport, because the turbine is regarded as a physical barrier and a possible interference to radio navigation systems $[20,24]$.

Analyzing in more detail the conditions for the implementation of wind energy in airports, it is mandatory in all cases to conduct a study of air traffic safety and radio navigation interferences, in order to choose the best location for wind turbines within the airport confines [31]. This study will require approval by the corresponding national aviation authority.

Ortega [31] also described a general approach regarding physical dimensions of the wind turbine for the implementation of wind power in airports, proposing the best solution to use the electricity produced (i.e., as a primary source synchronized with the commercial grid). This option allows self-sufficient use of wind energy, and if the power generated is not sufficient to supply the airport it could be complemented by power supplied from the grid.

\subsubsection{Hydroelectric Energy}

This type of renewable energy source uses water power to produce energy. A typical hydroelectric scheme is not possible in the context of airports unless the airport is near a large body of water that contains usable kinetic energy potential [4]. However, the environmental impact of developing a hydropower system near airports would make it unsuitable for most airport situations.

\subsubsection{Geothermal Energy}

Geothermal technologies utilize heat from the Earth. Airports have not been a viable source for conventional geothermal projects due to the specific geographic requirements and the focus on utility-scale electricity generation development due to its potential to be more cost effective [19]. On the other hand, geothermal energy based on heating and cooling takes advantage of the relatively uniform surface temperature of the ground, and thus can be used as a heat sink or source [4].

At an airport, large amounts of land available without interaction with aircraft could be used to implement such facilities [32]. At present, some examples of studies of geothermal energy are located at the Juneau Airport and Portland Jetport in Maine [19] or at the Thessaloniki airport in Greece [33]. 


\subsubsection{Biofuels}

Biofuels are produced from biomass, and it is possible to utilize them in internal combustion engines, which could be used for transportation vehicles on the airside of the airport [34], such as the luggage transportation vehicles at Munich airport [35].

\subsubsection{Biomass}

Biomass is organic material that comes from plants and animals. It can be gathered by the airport (such as food waste) and recycled at the site as an energy source, for example through gasification for CHP plants [15], or for obtaining hot water through boilers, as at the Stansted airport [36]. Such schemes could even be extended to include the collection of waste from surrounding areas [32].

\subsubsection{Biogas}

Biogas is produced from the anaerobic digestion of biomass in a natural and spontaneous way, and could be used at airports as an alternative to natural gas to heat or cool buildings or water [4].

\section{Energy Consumption}

Airports in general have high-energy consumption. Influenced by many factors, the characteristics of airport energy consumption are stochastic, nonlinear and dynamic [37]. Scientific research on energy consumption is mainly focused on terminal buildings, although these are only a part of the whole airport. Next, the main energy consumers in airports are described, dividing them between the main areas of an airport: airside and landside. In Figure 2, energy consumption at the Santander airport is shown, as an example.

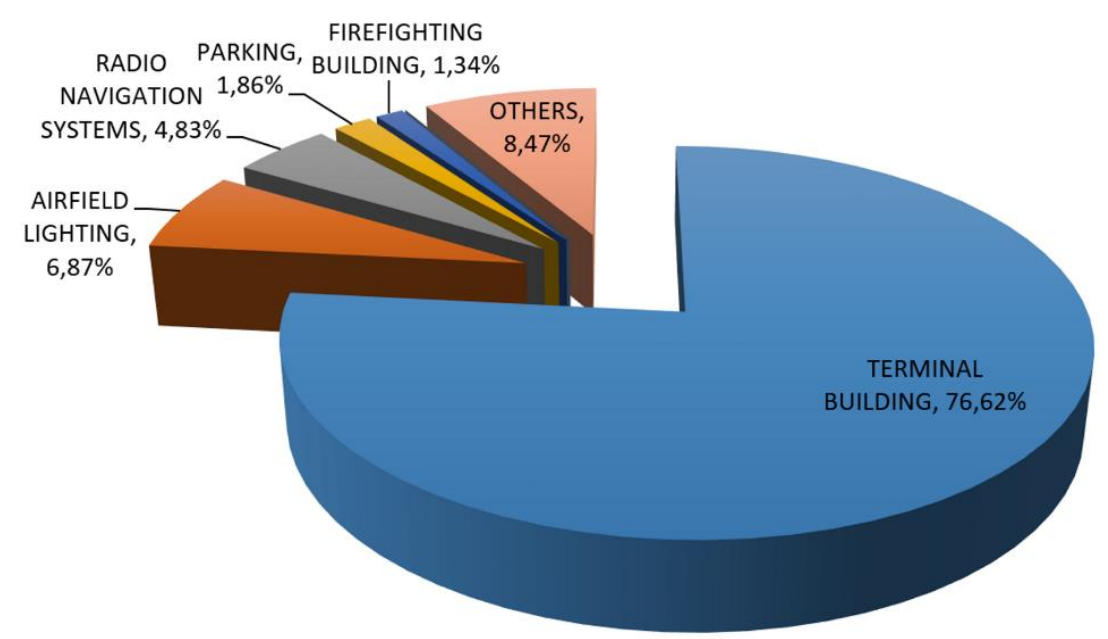

Figure 2. Energy consumption at Santander airport. Source: Airport Seve Ballesteros-Santander.

\subsection{Airside Consumption}

Airside energy consumers are fundamentally the airfield lighting and radio navigation systems, as well as any auxiliary buildings such as the control tower or hangers. At Santander Airport, airfield lighting and radio navigation systems account for between $5 \%$ and $7 \%$ each of the total airport electricity consumption (see Figure 2). The main factor in airside energy consumption is the size of the aircraft operation area (runway, taxiway and apron), due to its proportional influence on the number of airfield lights, and the operating hours of the airport during which landings and takeoffs for aircraft are allowed. This is because at airports with night air operations it is mandatory to switch on the airfield lighting. 


\subsection{Landside Consumption}

Landside energy consumers are fundamentally the terminal building or buildings of the airport. It is the largest energy consumer because of its function as a node for processing passengers and cargo and the large number of facilities required for its operation. HVAC, lighting and Information and Communications Technologies (ICT) systems are usually the largest energy consumers in terminal buildings. Next, the main factors studied by the scientific literature that affect the energy consumption of a terminal building are summarized in Table 3.

Table 3. Parameters that determine terminal building energy consumption.

\begin{tabular}{cccc}
\hline Building Characteristics & Climate & Comfort & Building Services \\
\hline Shape factor & Temperature & Thermal comfort & Operation hours \\
Compactness & Solar radiation & Visual comfort & $\begin{array}{c}\text { Energy management (BEMS) } \\
\text { Occupants' behavior }\end{array}$ \\
Transparent surface & Wind & Indoor air quality & \\
Orientation & Pluviometry & & \\
Building materials & Humidity & & \\
Passive systems & & & \\
\hline
\end{tabular}

BEMS, building energy management systems.

\subsubsection{Building Characteristics}

The building characteristics that most influence the energy performance of a particular building are analyzed by Pacheco et al. [38], although in a terminal building, as happens in other public service facilities, there are differentiating factors regarding commercial or residential buildings [39]. Features such as compactness, shape, orientation and shading, building envelope (walls, roof and windows), heated, cooled and illuminated surfaces are key factors in energy consumption. Nevertheless, energy consumption in a terminal building could be minimized if it is designed according to energy efficiency criteria, through bioclimatic architecture, whose main principles are described by Guillamón et al. [40].

Curtain walls and glass surfaces severely affect energy consumption in terminal buildings due to the fact that the envelope would be dominated by glass facades and skylights. This indoor thermal environment is characterized by high-intensity solar radiation and high-temperature. These issues have been studied by several authors. Mardaljevic [41] described a new image-based technique to quantify the effectiveness of shading devices in order to predict the impact of solar penetration into the glass roofs of Changui airport. Li et al. [42] studied the influence of curtain wall openings to minimize the need for HVAC systems, calculating an optimal opening during certain periods of the year at a southern China airport. Zhao et al. [43] studied the influence of a water curtain wall installed at the Nanjing airport and its influence on the energy efficiency of the terminal building. Tzempelikos [44] developed and implemented different lighting and shading control schemes at the terminal building of Montreal airport, expecting significant energy savings.

Other studies relate to the development of radiant floors at airports as this is an effective way to maintain comfort conditions in many large buildings. Zhao et al. [45] showed the application of radiant floors in large public buildings such as airports and presented a review of the newest techniques. Simmonds [46] described a cooling floor combined with a variable-volume conditioning system as a way to maintain comfort at the Bangkok airport. Such a conditioning system was previously proposed in [47]. Zhang et al. [48] analyzed the impact of an independent temperature and humidity control system combined with a radiant floor at the Xianyang airport, improving the previous energy performance. Olesen [49] presented a radiant floor application at the Thailand airport, in which the solar radiation entering through the terminal building is extracted by a radiant floor, reducing considerably the air supply. Yu et al. [50] developed an analytical and simulation model for the floor cooling system at the Eindhoven airport. Wu et al. [51] summarized a comparative analysis of indoor thermal conditions of two airports with radiant floor and traditional ventilation systems in China, 
and concluded that the radiant floor provides better temperature and humidity conditions with less energy consumption.

\subsubsection{Climate}

Climate conditions such as temperature, humidity, irradiation, and wind direction and speed are key factors of energy consumption in terminal buildings, focused mainly on the needs of HVAC systems and lighting [32]. During the winter season, the internal loads could exceed the thermal losses, forcing the HVAC system to operate in the cooling mode and not in heating, while during the summer the internal loads are added to the external ones due to the heat exchange by radiation, conduction and convection [13]. In relation to the wind, Neofytou et al. [52] investigated the thermal effect of the wind environment around a large airport terminal, in which CFD simulations have been performed.

\subsubsection{Comfort}

Comfort in buildings is mainly determined by three factors: thermal comfort, visual comfort and indoor air quality [53]. The indoor conditions are expected to provide a comfortable working environment for the terminal staff and at the same time a comfortable transient environment for passengers. The recommendations for airport terminals are temperatures between 23 and $26{ }^{\circ} \mathrm{C}$ and relative humidity $(\mathrm{RH})$ between $30 \%$ and $40 \%$ in winter, and $\mathrm{RH}$ between $40 \%$ and $55 \%$ in summer [53]. On the other hand, the Chartered Institution of Building Services Engineers (CIBSE) proposes thermal comfort criteria for specific terminal areas based on standard activity and clothing insulation [54]. In the case of Spain, airport managers have official regulations [55] that limit heating (not above 21 ${ }^{\circ} \mathrm{C}$ ) and cooling (not less than $26^{\circ} \mathrm{C}$ ) in public buildings with a surface larger than $1000 \mathrm{~m}^{2}$, which is directly applicable to airports.

Knowledge of the thermal requirements and acceptance by airport passengers and staff is a very important issue in order to optimize the different facilities involved. Kotopouleas et al. [56] presented the results of a study of thermal comfort conditions in three terminal buildings in the UK, suggesting that during winter, when overheating is more apparent, there may be a great potential for energy savings from lowering the heating systems set-points without compromising the thermal comfort conditions. Balaras et al. [39] summarized a study of levels of satisfaction showing different levels of acceptance among airport staff and passengers in Greek airports. Babu [57] analyzed a 128 respondent survey indicating that a temperature range of $24-32{ }^{\circ} \mathrm{C}$ is satisfactory for Ahmedabad airport passengers, highlighting that passengers while transitioning express a higher thermal tolerance from a familiar local environment to a conditioned environment, and a higher comfort expectation when transitioning from one conditioned space to another. Finally, Liu et al. [58] presented another study of satisfaction based on thermal levels at the airport in Chengdu with a $95.8 \%$ acceptation with comfort zone ranges from 19.2 to $23.1^{\circ} \mathrm{C}$ during winter and 23.9 to $27.3^{\circ} \mathrm{C}$ during summer.

\subsubsection{Building Services Operation}

As in the case of airside energy consumption, operation hours of the terminal building strongly determine the energy consumption due to the amount of energy consumed by the systems and facilities which are operational. Also, the significant variation of the population in the building in short periods of time affects the energy behavior of the building.

Unlike residential buildings or offices, behavioral patterns are largely transitional [7]. Therefore, occupation level is an important factor, with peaks and valleys of passengers depending on flight schedules, requiring an adaptation of the lighting and comfort conditions of certain areas. In recent years, strategies to reduce energy consumption based on building occupancy have been developed. Thus, Mambo et al. [59] studied various strategies to reduce energy consumption in HVAC systems and lighting based on the monitoring of existing occupancy through commercial software. In another study, Mambo et al. [60] presented the results of indoor environment measurement and flight schedules to identify opportunities to implement energy conservation measures in the passenger exclusive areas of 
the airport building, obtaining an energy saving of $20 \%-25 \%$ if indoor environment comfort set points are varied, while improving the thermal comfort of the passengers. In [61,62], a fuzzy methodology is proposed to optimally adapt lighting and temperature of the different rooms of the building, using as inputs the scheduled flight departure and arrival, the expected number of passengers and the existing lighting and outside temperature.

\subsubsection{Building Occupants' Behavior}

Building occupants' behavior and how to simulate its impact on energy consumption has been studied by Virote et al. [63] and Yu et al. [64]. In the case of airports, it is important to differentiate between scheduled and non-scheduled flights, due to their percentage impact on airport energy design [7]. The same occurs with passenger type: business passengers tend to use the airport more frequently and therefore are more familiar with its use and how to access it. These passengers usually spend less time at the terminal and spend less money in existing stores, but they do spend in restaurants and cafes [7]. Almost the opposite occurs with leisure passengers.

\section{Energy Conservation and Energy Efficiency}

In recent years, airport managers have made huge efforts to harmonize airport operation with environmental sustainability by minimizing the environmental impact, with energy conservation and energy efficiency as one of their pillars [65]. Airport managers usually show their efforts to reduce energy consumption through their own websites, publishing their yearly environmental reports, for example $[9,66,67]$.

Energy conservation is based on reducing energy consumption by reducing the quality of services offered, for example, decreasing the heating thermostat. It is strongly influenced by regulation, user behavior and changes in lifestyle [68]. However, energy efficiency means getting more for every unit of energy you gain without compromising comfort or safety [69].

One of the most important measures relating to conservation and energy efficiency at airports is associated with conducting an energy audit of the facilities [70]. With this audit, the way an airport consumes energy is analyzed, and it becomes easier to propose measures to improve energy performance.

The most important measures to reduce energy consumption at European airports in recent years are described by Rehault et al. [71]. These measures can be classified into the following categories: improvements in management systems and energy facilities, use of renewable energy technologies or CHP plants, new operational and maintenance procedures to improve and optimize equipment energy efficiency and improvements in HVAC and lighting, due to the fact that they are facilities with an intensive use of energy, as is shown in Figure 3 for the Seve Ballesteros-Santander airport.

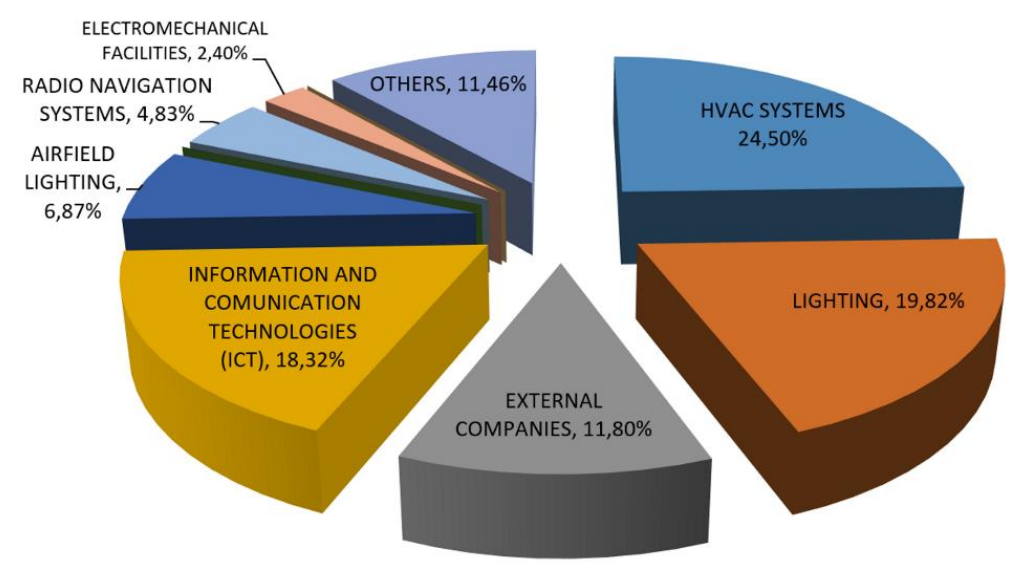

Figure 3. Energy consumption by facilities at Santander airport. Source: Airport Seve Ballesteros-Santander. 


\subsection{Lighting}

Lighting may represent an important part of the energy consumption of terminal buildings: 9.3\% at Soekarno-Hatta Menderes airport [72], 25\% at Tacoma airport [73], and 20\% at Santander Airport (see Figure 3). For that reason, lighting represents one of the best opportunities for energy savings at airports. Having a large number of operating hours, investments in efficient lighting provide excellent performance. This improvement can be achieved by various means [74]. Some examples are daylighting strategies [57], using presence detection systems in specific areas such as bathrooms and hallways [9], coordinating switch on and off illuminated areas depending on flight schedules [75], replacing conventional ballasts for electronic, installation of stabilizer energy equipment or the replacement of conventional light-emitting diode (LED) lights [13]. Airfield lighting contributes significantly to the energy consumption of an airport, but the reduction in consumption is often linked to an improvement of lamp efficiency, due to the restrictive regulations regarding airfield lighting when air traffic is operative.

\subsection{HVAC Systems}

Typically, thermally conditioned buildings aim to maintain a uniform thermal environment throughout the building, which would necessitate an energy intensive HVAC solution. These systems may represent a large part of the energy consumption of terminal buildings: $66 \%$ at Ahmedabad airport [57], 80\% at Adnan Menderes airport [76], 86\% at Soekarno-Hatta Menderes airport [75], 25\% at Tacoma airport [73], and 25\% at Santander Airport (see Figure 3). The choice of a suitable temperature setpoint operation [60], the utilization of natural ventilation [77], the usage of passive cooling strategies [57], the modeling and thermal simulation of the terminal building [78], as well as the HVAC management systems based on an hourly planification [61] and other similar measures [13,39,70,79], can make a huge difference in the total energy consumption compared to an initial situation without any control.

\subsection{Procedures}

Operational procedures, such as maintenance supervisions or the addition of electricity meters, allow a better consumption control of the facility [71]. These operational procedures are usually part of energy management systems, such as International Standards Organization (ISO 50.001), Airport Carbon Accreditation (ACA) or Leadership in Energy and Environmental Design (LEED) methodology, which allow the implementation of continuous improvement processes to increase the energy performance [71]. As a real example, Kilkiş and Kilkiş [80] presented the energy certification systems of nine important world airports, showing in all cases big improvements in energy consumption thanks to these management systems.

\subsection{Building Energy Management Systems}

Finally, the need to reduce energy consumption, while maintaining passenger comfort, leads researchers to develop building energy management systems (BEMS), especially for large buildings [81]. These systems are designed to monitor and control the environmental and operating parameters of the building and to minimize energy consumption and operating costs. In the case of an airport, BEMS can help to control systems ranging from the HVAC, lighting and electromechanical installations of the terminal building to the airfield lighting or power plants, as described by Ancevic [82] showing the latest developments in BEMS systems implemented at the Munich airport and equally by Falvo for the Rome airport [13].

\section{Energy Benchmarking}

In more recent research, the energy efficiency index is characterized through energy performance indicators (EPIs), which relate energy consumption generated in a particular process with indicators 
based on economic [83], thermodynamic or physical principles [84]. In the case of airports, the most commonly used EPIs are ( $\mathrm{kWh} /$ passenger (pax)), $(\mathrm{kWh} /$ terminal building surface) and (kWh/HVAC surface) [71].

Balaras et al. [39] evaluated various Greek airports obtaining the EPIs of their terminal buildings with values between $1.7 \mathrm{kWh} /$ pax and $2.75 \mathrm{kWh} /$ pax, classifying them according to their climatic zone, due to the great influence of the HVAC systems, and reporting an average EPI of $234 \mathrm{kWh} / \mathrm{m}^{2}$ for all Greek airports analyzed. In Spanish airports [9], this EPI was $210 \mathrm{kWh} / \mathrm{m}^{2}$ in 2014. An EPI of $263 \mathrm{kWh} / \mathrm{m}^{2}$ was obtained for the Ahmedabad airport [57] and an EPI of $210 \mathrm{kWh} / \mathrm{m}^{2}$ at Adnan Menderes airport [76]. In relation to European airports, London Heathrow, Paris Charles de Gaulle and Frankfurt are well above other airports in energy consumption, but if this value is normalized to the number of passengers, values of $13.57,17.93$ and $15.69 \mathrm{kWh}$ / pax are obtained, within the mean of European airports [71]. The results also show that there is not a linear relationship between the size of the airport and its energy consumption, because of the multiple factors involved, as shown in Table 4 .

Table 4. Energy benchmarking in European airports in 2009. Source: [71].

\begin{tabular}{cc}
\hline Airport & EPI (kWh/pax· year) \\
\hline London (LHR) & 13.57 \\
Paris (CDG) & 17.93 \\
Frankfurt (FRA) & 15.69 \\
Madrid (MAD) & 7.19 \\
Amsterdam (AMS) & 7,61 \\
Rome (FCO) & 7.24 \\
Istanbul (IST) & 8.00 \\
Zurich (ZRH) & 13.96 \\
Mallorca (PMI) & 3.87 \\
Munich (MUC) & 11.53 \\
Barcelona (BCN) & 6.30 \\
Brussels (BRU) & 10.90 \\
Lisbon (LIS) & 8.52 \\
Edinburgh (EDI) & 3.95 \\
Manchester (MAN) & 12.48 \\
Oslo (OSL) & 4.31 \\
\hline
\end{tabular}

EPI, energy performance indicators; pax, passenger.

These EPIs provide energy managers with information about energy performance, but they do not provide information about the reasons behind good or bad energy consumption, and cannot be used directly for benchmarking with other airports due to the different situations and factors which are involved. These EPIs can even be part of a greater environmental sustainability index, as in the case of Kilkiş, B. [85], who proposed a series of indicators to assess the environmental impact at the new Istanbul International airport, including energy indicators, or Upham [65], who presented various sustainability indexes for Manchester Airport. Likewise, Chen et al. [86] described an analytic hierarchy process and grey correlation analysis to evaluate a calculation of the energy consumption index of airports. Finally, Kilkiş and Kilkiş [80] presented a sustainability ranking for nine airports, based on an index that allows coordinating strategies for the sustainable development of energy systems.

\section{Energy Modeling}

Energy modeling seeks to quantify energy consumption based on input parameters. Modeling to predict energy consumption at airports can provide effective decision support for using energy more rationally and carrying out energy-saving measures.

Several energy modeling research studies are related to energy prediction for terminal buildings. Prediction methods may include neural networks, grey prediction, regression analysis, and some combination of prediction methods. Chen [87] proposed a prediction model based on unbiased grey 
Markov models, performed analyses of five Chinese airports and obtained accurate consumption trends at the terminal building compared to a traditional grey Markov model. Due to the nonlinearity of the thermal dynamics of a terminal building, Huang et al. in [88,89] presented a hybrid scheme based on model predictive control and neural network feedback linearization which can minimize the energy and cost of running HVAC systems in terminal buildings, which was simulated at Adelaide airport. Again, Huang et al. in [90] evaluated a resistance-capacitance (RC) thermal network to obtain savings between $5 \%$ and $18 \%$ over the daily energy consumption at Adelaide airport. Other authors have proposed hybrid methods based on a neural network combined with grey methodology [91], with a prediction accuracy that can be controlled within $7 \%$.

Energy performance improvements of traditional HVAC systems by modeling parameters without reducing comfort and air quality are also very important fields in scientific research. Thus, Fan et al. [92] developed models to optimize HVAC systems at airports based on probability density distribution of cooling load ratio, achieving improvements between $1.4 \%$ and $4.3 \%$, taking Haikou airport in China as a model. Dai et al. [78] modeled the operating conditions of HVAC systems at Guilin airport, analyzing the influence of chilled water temperature on water chiller performance. Sun et al. [93] proposed the integration and optimization of HVAC systems in neighboring buildings at Hong Kong airport, obtaining an improvement in system performance of 5.93\%. Muller, Blanes y Costa [94-96] described the results of a model to improve the steady failure detection in HVAC systems through information and communications technologies (ICT), and thus try to reduce no operation time of these systems. Perdamaian et al. [72] analyzed the energy consumption and $\mathrm{CO}_{2}$ emissions at Soekarno-Hatta airport, simulating different scenarios of HVAC systems to reduce the final consumption. Montgomery et al. [97] developed a model to predict the energy efficiency of different filters for HVAC machines at Vancouver airport. Finally, Fan et al. [98] proposed a model for evaluating the energy efficiency of HVAC systems of a terminal building based on an exergy analysis.

\section{Energy Simulation}

Energy simulation tools predict the energy performance of a given building and the thermal comfort of its occupants. Energy simulation began in the 70s as a preliminary technical phase before the construction of a building and has matured since then with the evolution of computing [99].

Several scientific publications are focused on thermal simulations to improve the energy efficiency at terminal buildings. Balaras et al. [39] analyzed the thermal simulation of different scenarios of energy conservation at Greek airports, obtaining potential savings between $15 \%$ and $35 \%$ without compromising quality or comfort. Liu et al. [58] studied the simulation of the indoors thermal conditions at Chengdu airport using computational fluid dynamics methodologies (CFD). Likewise, Ma et al. [100] taking advantage of this CFD methodology, established the relationship between indoor air flow and interior space, reducing the internal temperature and improving indoor comfort at Beijing airport. Raymond et al. [101] used small-scale fluid dynamics modeling to optimize the design of air distribution in a large airport. Meng et al. [77] simulated by CFD the potential of natural ventilation and air modulation by mechanical fans under typical meteorological conditions at Sanya airport, concluding that wide usage of this equipment in tropical zones could lead to lower energy consumption.

In other scientific studies, commercial energy simulation programs are used. Griffith et al. [102] used EnergyPlus to study the influence of advanced envelope technologies in a fire fighting building at Teterboro airport. Zeren [76] simulated by EnergyPlus and DesignBuilder the energy influence of HVAC systems at Adnan Menderes airport, and evaluated various energy conservation strategies such as variation of building orientation and HVAC systems, with the results serving as a basis for large buildings with glazed surfaces. Chen et al. [37] presented the simulation model of HVAC systems at a terminal building by EnergyPlus, highlighting that decreasing the supply air temperature has a favorable impact on energy saving. Fang et al. [103] simulated the operating parameters that influence HVAC systems using multi-variate regression models at Hainan airport, proposing a method of hierarchal cluster to categorize chillers' operating condition by extracting operating parameters which 
have evident influence on chillers' operation as the cluster parameter. Parker et al. [104] presented the results of several improvements in the envelope and glazed roof at a UK airport and their impact on reducing the carbon footprint. Liu et al. [105] analyzed by Transient Systems Simulation Program (TRNSYS) the dynamic load simulation of a curtain wall at Tianjin Airport, weighing the huge impact of solar radiation on energy consumption and proposing a guide to improve its design. Falvo et al. [13], by applying Design Builder and EnergyPlus, described the dynamic thermal simulation at Rome airport to determine the primary energy consumption, based on passenger flow contributions and transit equipment. Sangiorgi et al. [106] simulated the real conditions of a HVAC system at a small Spanish airport by TRNSYS to minimize energy consumption. Gowreesunker et al. [107] simulated by TRNSYS-CFD the airflow inside the airport terminal space reporting that the displacement ventilation system is more efficient for cooling than heating a space.

\section{Conclusions}

Airports in general have high-energy consumption. Influenced by many factors, the characteristics of airport energy consumption are stochastic, nonlinear and dynamic. In scientific research, energy consumption is mainly focused on terminal buildings, although these are only a part of the whole airport, so a greater depth in all aspects influencing the energy performance in airports is a promising future research field.

The main energy consumers in airports can be divided between the airside and landside of the airport. Airside energy consumers are fundamentally the airfield lighting and radio navigation systems. Landside energy consumers are fundamentally the terminal building of the airport due to its function as a node for processing passengers and cargo and the large number of facilities required for its operation. HVAC, lighting and ICT systems are usually the most important energy consumers at airports, so it is essential to study new methods to achieve a reduction in energy consumption in these kind of facilities.

Electricity is the dominant energy source because it is necessary for the supply of the main airport energy consumers and to ensure the safety of air traffic operations. This electricity usually comes from the commercial grid and is supplied by a power company. However, during the last several years it is possible to find in the scientific literature and at airports other kinds of energy sources such as CHP plants or renewable energy technologies. Nevertheless, given their special characteristics and the effect on air traffic safety, it is essential to set in a near future rules that make compatible airports and these kind of energy sources.

Nowadays energy consumption reduction is a priority for airport managers. Most important measures can be classified into the following categories: improvements in management systems and energy facilities, improvements in HVAC systems and lighting, and new operational management systems that help to improve and optimize airport energy efficiency.

Likewise, modeling and simulation of energy consumption at airports can be an important factor in lowering consumption. Therefore, the development of more accurate methods for the airport environment is necessary, but they should focus on airports globally and not only on the terminal building. Finally, the utilization of EPIs provides energy managers with information about energy performance, but does not provide information about the reasons for good or bad energy consumption, and they cannot be used directly for benchmarking with other airports due to the different situations and factors which are involved. It is necessary to develop new specific benchmarking methods for airports, which take into account their characteristics and make them comparable with each other.

Author Contributions: Sergio Ortega Alba conceived the initial idea and structure of the manuscript and recollect the energy data of Spanish airports and Seve Ballesteros-Santander airport. Both Sergio Ortega Alba and Mario Mañana Canteli analyzed and summarized the current state-of-the-art of energy behavior and trends in airports.

Conflicts of Interest: The authors declare no conflict of interest. 


\section{Abbreviations}

The following abbreviations are used in this manuscript:

$\begin{array}{ll}\text { AENA } & \text { Aeropuertos Españoles y Navegación Aérea (In Spanish) } \\ \text { ASHRAE } & \text { American Society of Heating, Refrigeration and Air-Conditioning Engineers } \\ \text { BEMS } & \text { Building energy management systems } \\ \text { CHP } & \text { Combined heat and power } \\ \text { CHCP } & \text { Combined heat, cooling and power } \\ \text { CIBSE } & \text { Chartered Institution of Building Services Engineers } \\ \text { CFD } & \text { computational fluid dynamics } \\ \text { EPI } & \text { Energy performance indicators } \\ \text { GDP } & \text { Gross domestic product } \\ \text { HVAC } & \text { Heating, ventilation and air conditioning } \\ \text { ICAO } & \text { International Civil Aviation Organization } \\ \text { ISO } & \text { International Standards Organization } \\ \text { LED } & \text { Light-emitting diode } \\ \text { Pax } & \text { Passenger } \\ \text { RH } & \text { Relative humidity } \\ \text { TRNSYS } & \text { Transient Systems Simulation Program } \\ \text { UK } & \text { United Kingdom }\end{array}$

\section{References}

1. International Energy Agency. International Energy Outlook 2011. Available online: https:/ /www.iea.org/ publications/freepublications/.../WEO2011_WEB.pdf (accessed on 15 January 2016).

2. International Energy Agency. International Energy Outlook 2015. Available online: http://www. worldenergyoutlook.org/weo2015/ (accessed on 15 January 2016).

3. Pérez-Lombard, L.; Ortiz, J.; Pout, C. A review on buildings energy consumption information. Energy Build. 2008, 40, 394-398. [CrossRef]

4. Rowlings, A.; Arron, R. Sustainable Energy Options for the Future Airport Metropolis. In Proceedings of the 4th IASME/WSEAS International Conference (EEESD'08), Algarve, Portugal, 11-13 June 2008.

5. Airports Council International Europe (ACI Europe). ACI-Europe Statistics. Available online: https: //www.aci-europe.org/ (accessed on 1 February 2016).

6. International Civil Aviation Organization (ICAO). Aerodrome Design and Operations, 5th ed.; ICAO: Montreal, QC, Canada, 2009.

7. Ashford, N.; Mumayiz, S.; Wright, P. Airport Engineering, 4th ed.; John Wiley \& Sons Inc.: Hoboken, NJ, USA, 2009.

8. Reynolds, T.; Neufville, R.; Beloboba, P.; Odoni, A. Airport Systems, Planning, Design and Management, 2nd ed.; McGraw-Hill Professional: New York, NY, USA, 2013.

9. Aeropuertos Españoles y Navegación Aérea (AENA). Corporate Responsability Report 2014, 1st ed.; AENA: Madrid, Spain, 2015; Available online: http://www.aena.es/csee/Satellite/sostenibilidad/es/Page/ 1237564421395//Informe-anual.html (accessed on 1 February 2016).

10. Ionita, C.; Marinescu, M. A review of combined heat and power generation. Sci. Bull. Ser. D Mech. Eng. 2002, $64,71-80$.

11. Cardona, E.; Piacentino, A.; Cardona, F. Energy saving in airports by trigeneration. Part I: Assessing economic and technical potential. Appl. Ther. Eng. 2006, 26, 1427-1436. [CrossRef]

12. Somcharoenwattanaa, W.; Menkea, C.; Kamolpusb, D.; Gvozdenac, D. Study of operational parameters improvement of natural-gas cogeneration plant in public buildings in Thailand. Energy Build. 2011, 43, 925-934. [CrossRef]

13. Falvo, M.C.; Santi, F.; Acri, R.; Manzan, E. Sustainable airports and NZEB: The real case of Rome International Airport. In Proceedings of the 15th International Conference on Environment and Electrical Engineering (EEEIC), Rome, Italy, 10-13 June 2013; pp. 1492-1497. 
14. Naples, T.F.; Hegebarth, D.G. Remote monitoring and display of onsite cogeneration systems performance-an update. In Proceedings of the 21st Intersociety Energy Conversion Engineering Conference: Advancing Toward Technology Breakout in Energy Conversion, San Francisco, CA, USA, 19 August 1984; American Chem. Soc.: Washington, DC, USA, 1996.

15. Altenbach, W. Combined DH/Cooling Generation of Terminal 2 Airport Frankfurt Rhein/Main. In Proceedings of the Euroheat \& Power Fernwaerme International, Frankfurt, Germany, 15 June 1996.

16. Santoli, L.; Mancini, F.; Nastasi, B.; Piergrossi, V. Building integrated bioenergy production-Economic sustainability analysis of Bari airport combined heat and power upgrade fueled with bioenergy from short chain. Renew. Energy 2015, 81, 499-508. [CrossRef]

17. Cardona, E.; Piacentino, A.; Cardona, F. Energy saving in airports by trigeneration. Part II: Short and long term planning for the Malpensa 2000 CHCP plants. Appl. Ther. Eng. 2006, 26, 1437-1447. [CrossRef]

18. Panwar, N.L.; Kauhik, S.C.; Kothari, S. Role of renewable energy sources in environmental protection: A review. Renew. Sustain. Energy Rev. 2011, 15, 1513-1524. [CrossRef]

19. Airport Cooperative Research Program. Report 141: Renewable Energy as an Airport Revenue Source; Transportation Research Board: Washington, DC, USA, 2015.

20. Airport Cooperative Research Program. Report 28: Investigating Safety Impacts of Energy Technologies on Airports and Aviation; Transportation research board: Washington, DC, USA, 2011.

21. Mekhilef, S.; Saidur, R.; Safari, A. A review on solar energy use in industries. Renew. Sustain. Energy Rev. 2011, 15, 1777-1790. [CrossRef]

22. Ruther, R.; Braun, P. Energetic contribution potential of building-integrated photovoltaics on airports in warm climates. Sol. Energy 2009, 83, 1923-1931. [CrossRef]

23. Zomer, C.; Costa, M.; Nobre, A.; Ruther, R. Performance compromises of building-integrated a building-applied photovoltaics (BIPV and BAPV) in Brazilian Airports. Energy Build. 2013, 66, 607-615. [CrossRef]

24. Barret, S.; Devita, P.; Ho, C.; Miller, B. Energy technologies' compatibility with airports and airspace: Guidance for aviation and energy planners. Airpt. Manag. 2014, 8, 318-326.

25. Schiavoni, M.; Gayout, P.; Berard, M.; Nositschka, W.A.; Neumann, D.; Nicklas, D. Anti-glare effect of deeply textured cover glasses for solar modules for installations close to airports and heliports. In Proceedings of the 28th European Photovoltaic Solar Energy Conference and Exhibition, Paris, France, 30 September-4 October 2013.

26. Plante, J.A.; Barrett, S.B.; De Vita, P.M.; Miller, R. Report No. FAA-ARP-TR-10-1: Technical Guidance for Evaluating Selected Solar Technologies on Airports; Federal Aviation Administration, US Department of Transportation: Washington, DC, USA, 2010.

27. Wybo, J. Large-scale photovoltaic systems in airport areas: Safety concerns. Renew. Sustain. Energy Rev. 2013, 21, 402-410. [CrossRef]

28. DeVault, T. Bird use of solar photovoltaic installations at US airports: Implications for aviation safety. Landsc. Urban Plan. 2014, 122, 122-128. [CrossRef]

29. Braun, P.; Wille-Haussmann Ruther, R.; Wittwer, C. Solar Energy on Airports: The impact of large scale photovoltaic systems on distribution networks. In Proceedings of the 23rd European Photovoltaic Solar Energy Conference and Exhibition, Valencia, Spain, 1-5 September 2008.

30. Ruther, R.; Braun, P. A future multi-billion Euro PV market? Refocus 2005, 6, 30-34. [CrossRef]

31. Ortega, S. Conditioning for the implementation of wind energy in airports. DYNA Energía y Sostenibilidad 2013, 2. [CrossRef]

32. Koroneos, C.; Xydis, G.; Polyzakis, A. The optimal use of renewable energy sources-The case of the new international airport of Thessaloniki, Greece. Renew. Sustain. Energy Rev. 2010, 14, 1622-1628. [CrossRef]

33. Mendrinos, D.; Karytsas, C. Use of Geothermal Energy at the New Building Installations of the Airport Makedonia. In Proceedings of the 1st International Conference Airports: Planning and Operation, Thessaloniki, Greece, 11-12 June 2003.

34. Agarwal, R.K. Environmentally responsible air and ground transportation. In Proceedings of the 49th AIAA Aerospace Sciences Meeting including the New Horizons Forum and Aerospace Exposition, Orlando, FL, USA, 4-7 January 2011.

35. Munich Airport. Ground Service Vehicles to Run on Biofuel. Available online: http:/ /www.munich-airport. de/en/company/facts/programm/umwelt1/index.jsp (accessed on 15 January 2016). 
36. Stansted Airport. Stansted Airport to Install Gilles Biomass Boiler. Available online: http:/ /advantageaustria. org/gb/news/local/2007--09--10-gilles.en.jsp (accessed on 15 January 2016).

37. Yang, C.; Jin, X.; Du, Z.; Fan, B.; Yang, X. Modeling and simulation of the airport terminal air conditioning system based on Energyplus. J. Shanghai Jiaotong Univ. 2010, 44, 745-748.

38. Pacheco, R.; Ordoñez, J.; Martínez, G. Energy efficient design of a building: A review. Renew. Sustain. Energy Rev. 2012, 16, 3559-3573. [CrossRef]

39. Balaras, C.A.; Dascalaki, E.; Gaglia, A.; Droutsa, K. Energy conservation potential, HVAC installations and operational issues in Hellenic airports. Energy Build. 2003, 35, 1105-1120. [CrossRef]

40. Guillamón, J.M.; García-Galludo, M. Gestión Energética y Medioambiental en Instalaciones Aeroportuarias, 1st ed.; Fundacion AENA: Madrid, Spain, 2004. (In Spanish)

41. Mardaljevic, J. Spatio-temporal dynamics of solar shading for a parametrically defined roof system. Energy Build. 2004, 36, 815-823. [CrossRef]

42. Li, Q.; Meng, Q.; Zhao, L. Energy efficiency design of an airport terminal building. In Proceedings of the International Conference on Advances in Energy Engineering (ICAEE 2010), Beijing, China, 19-20 June 2010.

43. Zhao, F.; Zhang, S.; Cai, Z. Energy analysis of the water curtain wall in terminal envelope. Build. Energy Effic. 2014, 42, 55-59.

44. Tzempelikos, A. Development and implementation of lighting and shading control algorithms in an aiport building. J. Arch. Eng. 2012, 18, 242-250. [CrossRef]

45. Zhao, K.; Liu, X.; Jiang, Y. Application of radiant floor cooling in large space buildings-A review. Renew. Sustain. Energy Rev. 2016, 55, 1083-1096. [CrossRef]

46. Simmonds, P. Using radiant cooled floors to condition large spaces and maintain comfort conditions. Trans. ASHRAE 2000, 106, 695-701.

47. Simmonds, P. Using CFD to analyze temperature stratification in a large airport building. In Proceedings of the ASME Fluid Conference, San Diego, CA, USA, 7-11 July 1996.

48. Zhang, T.; Liu, X.; Zhang, L.; Jiang, J.; Zhou, M.; Jiang, Y. Performance analysis of the air-conditioning system in Xi'an Xianyang International Airport. Energy Build. 2013, 59, 11-20. [CrossRef]

49. Olesen, B.W. Radiant floor cooling systems. ASHRAE J. 2008, 50, 16-22.

50. Yu, B.; Ruchti, J.P.; Luscuere, P.G. Numerical evaluation on floor cooling capacity in an airport. In Proceedings of the Building Simulation, Beijing, China, 27-30 July 2007.

51. Wu, M.; Liu, X.; Zhao, K.; Zhen, Y. Testing and comparative analysis on indoor thermal environments in the large space building or airport. In Proceedings of the 13th International Conference on Indoor Air Quality and Climate, Hong Kong, China, 7 July 2014; pp. 503-510.

52. Neofytou, P.; Venetsanos, A.G.; Vlachogiannis, D.; Bartzis, J.G.; Scaperdas, A. A CFD simulations of the wind environment around an airport terminal building. Environ. Model. Softw. 2006, 11, 520-524. [CrossRef]

53. American Society of Heating, Refrigeration and Air-Conditioning Engineers (ASHRAE). Standard 55-2004: Thermal Environmental Conditions for Human Occupancy; ASHRAE: Atlanta, GA, USA, 2004.

54. Chartered Institution of Building Services Engineers (CIBSE). Chapter 1: Environmental Criteria for Design. Guide A, Environmental Design, 7th ed.; CIBSE: London, UK, 2006.

55. Spanish Royal Decree 1826/2009: Regulations of Heating Systems in Buildings; State Official Newsletter: Madrid, Spain, 2009; pp. 104924-104927. (In Spanish)

56. Kotopouleas, A.; Nikolopoulou, M. Understanding thermal comfort conditions in airport terminal buildings. In Proceedings of the 8th Windsor Conference: Counting the Cost of Comfort in a Changing World, London, UK, 1-3 September 2014.

57. Babu, A.D. A Low energy passenger terminal building for Ahmedabad airport, India in building envelope as an environment regulator. In Proceedings of the 25th Conference on Passive and Low Energy Architecture, Dublin, Ireland, 22-24 October 2008.

58. Liu, J.; Yu, N.; Lei, B.; Rong, X.; Yang, L. Research on indoor environment for the terminal 1 of Chengdu Shuangliu international airport. In Proceedings of the 11th International IBPSA Conference, Glasgow, UK, 27-30 July 2009.

59. Mambo, A.D.; Efthekhari, M.; Thomas, S.; Steffen, T. Occupancy-Driven supervisory control strategies to minimise energy consumption of airport terminal building. Sustain. Energy Build. 2013, 22, 479-489.

60. Mambo, A.D.; Efthekhari, M.; Thomas, S.; Steffen, T. Evaluation of Indoor Environment System Performance for Airport Buildings. Int. J. Sustain. Green Energy 2015, 4, 73-84. 
61. Mambo, A.D.; Efthekhari, M.; Thomas, S.; Steffen, T. Fuzzy supervisory control strategies to minimise energy use of airport terminal buildings. In Proceedings of the 18th International Conference on Automation and Computing (ICAC), Loughborough, UK, 7-8 September 2012.

62. Mambo, A.D.; Efthekhari, M.; Thomas, S.; Steffen, T. Designing an occupancy flow-based controller for airport terminals. Build. Serv. Eng. Res. Technol. 2015, 36, 51-66. [CrossRef]

63. Virote, J.; Neves-Silva, R. Stochastic models for building energy prediction based on occupant behavior assessment. Energy Build. 2012, 53, 183-193. [CrossRef]

64. Yu, Z.; Benjamin, C.M.; Fung, B.; Haghighat, F.; Yoshino, H.; Morofsky, E. A systematic procedure to study the influence of occupant behavior on building energy consumption. Energy Build. 2011, 43, 1409-1417. [CrossRef]

65. Upham, P. A comparison of sustainability theory with UK and European airports policy and practice. J. Environ. Manag. 2001, 63, 237-248. [CrossRef] [PubMed]

66. London Heathrow Airport. Environmental Report 2014. Available online: http://www.heathrow.com/ company/community-and-environment/responsible-heathrow/reports-and-further-reading (accessed on 15 January 2016).

67. Frankfurt airport. Environmental Report 2014. Available online: http://www.fraport.com/en/sustainability. html (accessed on 15 January 2016).

68. Herring, H. Energy efficiency-A critical view. Energy Policy 2006, 3, 10-20. [CrossRef]

69. Patterson, M. What is energy efficiency? Concepts, indicators and methodological issues. Energy Policy 1995, 24, 377-390. [CrossRef]

70. Keane, M.; Costa, A.; Blanes, L.; Donnelly, C.; Torrens, I. Cascade Methodology for Energy Efficient Airports. Project Cascade European FP7. Available online: http://www.cascade-eu.org/cms/index.php? id=publications (accessed on 2 February 2016).

71. Rehault, N.; Ohr, F.; Maier, R. Online Survey on European Airports Energy Operation. Project Cascade European FP7. Available online: http://www.cascade-eu.org/cms/index.php?id=publications (accessed on 3 February 2016).

72. Perdamaian, L.; Budiarto, R.; Ridwan, M. Scenarios to reduce electricity consumption on $\mathrm{CO}_{2}$ emission at terminal 3 Soekarno-Hatta International Airport. Procedia Environ. Sci. 2013, 17, 576-585. [CrossRef]

73. Tacoma Airport. Improving Building Efficiency at Seattle-Tacoma International Airport; Clean Airport Partnership Inc.: Lakewood, CO, USA, 2004; pp. 4-5.

74. Costa, A.; Blanes, L.; Donnelly, C.; Keane, M. Review of EU Airport Energy Interests and Priorities with Respect to ICT, Energy Efficiency and Enhanced Building Operation. Project Cascade European FP7. Available online: http://www.cascade-eu.org/cms/index.php?id=publications (accessed on 4 February 2016).

75. Yang, L.; Li, K.; Yang, G.; Zhang, C. The design of airport flood lighting energy-saving control system. Appl. Mech. Mater. 2014, 492, 499-502. [CrossRef]

76. Zeren, F. Energy Performance Analysis of Adnan Menderes International Airport. Master's Thesis, Science in Energy Engineering, Izmir Institute of Technology, Izmir, Turkey, March 2010.

77. Meng, Q.L.; Chen, Z.L. Simulation and research on indoor environment control mode basing on thermal comfort: A case study in the aviation building in Sanya airport. In Proceedings of the 10th Conference of the International Building Performance Simulation Association, Beijing, China, 3-6 September 2007; pp. 161-168.

78. Dai, M.H.; Zhou, Z.P.; Xue, X. Test and Energy Consumption Analysis of Air-Conditioning Systems in Terminal Building of Guilin Liangjiang International Airport. Appl. Mech. Mater. 2012, 170-173, 2652-2656. [CrossRef]

79. Vakiloroaya, V.; Samali, B.; Fakhar, A.; Pishghadam, K. A review of different strategies for HVAC energy saving. Energy Convers. Manag. 2014, 77, 738-754. [CrossRef]

80. Kilkiş, Ş.; Kilkiş, Ş. Benchmarking airports based on a sustainability ranking index. J. Clean. Prod. 2015. [CrossRef]

81. Dounis, A.I.; Caraiscos, C. Advanced control systems engineering for energy and comfort management in a building environment-A review. Renew. Sustain. Energy Rev. 2008, 13, 1246-1261. [CrossRef]

82. Ancevic, M. Intelligent building system for airport. ASHRAE J. 1997, 39, 31-35.

83. Ang, B. Monitoring changes in economy-wide energy efficiency: From energy-GDP ratio to composite efficiency index. Energy Policy 2006, 34, 574-582. [CrossRef] 
84. Rodríguez-Gonzalez, A.; Vinagre-Diaz, J.; Caamaño, A.; Wilby, M.R. Towards a universal energy efficiency index for buildings. Energy Build. 2011, 43, 980-987.

85. Kilkiş, B. Energy consumption and $\mathrm{CO}_{2}$ emission responsibilities of terminal buildings: A case study for the future Istanbul International Airport. Energy Build. 2014, 76, 109-118. [CrossRef]

86. Chen, J.; Qian, X.; Sun, M. An energy efficiency assessment method based on grey correlation degree analysis for transport airport. Adv. Mater. Res. 2012, 616-618, 1195-1201. [CrossRef]

87. Chen, J.; Xie, K. A prediction model based on unbiased grey Markov for airport energy consumption prediction. In Proceedings of the 2013 Chinese Automation Congress (CAC), Changsha, China, 7-8 November 2013.

88. Huang, H.; Chen, L. A hybrid model predictive control scheme for energy and cost saving in commercial buildings: Simulation and experiment. In Proceedings of the American Control Conference (ACC), Chicago, IL, USA, 1-3 July 2015; pp. 256-261.

89. Huang, H.; Chen, L. A new model predictive control scheme for energy and cost saving in commercial buildings: An airport terminal building study. Build. Environ. 2015, 89, 203-216. [CrossRef]

90. Huang, H.; Chen, L. Model predictive control for energy-efficient buildings: An airport terminal building study. In Proceedings of the 11th IEEE International Conference on Control \& Automation (ICCA), Taichung, China, 18-20 June 2014.

91. Chen, J.; Xiao, W.; Qian, G. Prediction of airport energy consumption using a hybrid grey neural network model. Adv. Mater. Res. 2012, 608-609, 1252-1256. [CrossRef]

92. Fan, B.; Jin, X.; Du, Z. Optimal control strategies for multi-chiller system based on probability density distribution of cooling load ratio. Energy Build. 2011, 43, 2813-2821. [CrossRef]

93. Sun, Y.; Wang, S.; Cui, B.; Yim, S.C. Energy performance enhancement of Hong Kong international airport through chilled water system integration and control optimization. Appl. Ther. Eng. 2013, 11, 303-315. [CrossRef]

94. Muller, T.; Rehault, N.; Rist, T. A Qualitative Modeling Approach for Fault Detection and Diagnosis on HVAC Systems. Project Cascade European FP7. Available online: http://www.cascade-eu.org/cms/index. php?id=publications (accessed on 2 February 2016).

95. Blanes, L.; Costa, A.; Rehault, N.; Keane, M. Integration of Fault Detection and Diagnosis with Energy Management and Maintenance of HVAC Systems. Project Cascade European FP7. Available online: http: //www.cascade-eu.org/cms/index.php?id=publications (accessed on 2 February 2016).

96. Costa, A.; Sterling, R.; Blanes, L.; Howley, M.; Keane, M. A SWOT framework to investigate the integration between management systems and fault detection and diagnosis tools. In Proceedings of the International Conference on Applied Energy, Pretoria, South Africa, 1-4 July 2013.

97. Montgomery, J.; Green, S.; Rogak, S.; Bartlett, K. Predicting the energy use and operation cost of HVAC air filters. Energy Build. 2012, 47, 643-650. [CrossRef]

98. Fan, B.; Jin, X.; Du, Z. The method of evaluation operation performance of HVAC system based on exergy analysis. Energy Build. 2014, 77, 332-342. [CrossRef]

99. Crawley, B.; Hand, J.W.; Kummert, M.; Griffith, B.T. Contrasting the capabilities of building energy performance simulation programs. Build. Environ. 2008, 43, 661-673. [CrossRef]

100. Ma, J.S.; Liu, X.T.; Zhuang, D.M.; Wang, S.G. CFD-based design of the natural ventilation system of the traffic center of T3 Beijing International Airport. Adv. Mater. Res. 2011, 291-294, 3292-3295. [CrossRef]

101. Raymond, M.H. Air flow analysis for large spaces: Computational fluid dynamics and reduced-scale physical model tests. In Proceedings of the Asian Pacific Conference on Computational Mechanics, Hong Kong, China, 26 November 1991; pp. 1705-1711.

102. Griffith, B.; Pless, S.; Talbert, B.; Deru, M.; Torcellini, P. Energy Design Analysis and Evaluation of a Proposed air Rescue and Firefighting Administration Building for Teterboro Airport; National Renewable Energy Laboratory Golden: Washington, DC, USA, 2003.

103. Fang, X.; Jin, X.; Fan, B.; Du, Z.; Zeng, X. Evaluation on air conditioning's operating property of airport terminal based on hierarchal cluster. CIESC J. 2012, 36, 89-94.

104. Parker, J.; Cropper, P.; Shao, L. Using building simulation to evaluate low carbon refurbishment options for airport buildings. In Proceedings of the 12th Conference of International Building Performance Simulation Association, Sydney, Australia, 14-16 November 2011. 
105. Liu, K.; Zhu, N.; Tian, Z.; Wang, M.L. Analysis of energy-saving design of glass curtain wall in the terminal. Adv. Mater. Res. 2011, 280, 110-113. [CrossRef]

106. Sangiorgi, M.; Maellas, J.; Sanglier, G. Energy consumption optimization of a small Spanish airport. In Proceedings of the 9th International IBPSA Conference, Montreal, QC, Canada, 15-18 August 2005.

107. Gowreesunker, B.L.; Tassou, S.A.; Kolokotroni, M. Coupled TRNSYS-CFD simulations evaluating the performance of PCM plate heat exchangers in an airport terminal building displacement conditioning system. Build. Environ. 2013, 65, 32-145. [CrossRef]

(c) 2016 by the authors; licensee MDPI, Basel, Switzerland. This article is an open access article distributed under the terms and conditions of the Creative Commons Attribution (CC-BY) license (http:/ / creativecommons.org/licenses/by/4.0/). 